\title{
IDENTIFIKASI POTENSI BAHAYA K3 MENGGUNAKAN METODE FAILURE MODE EFFECT ANALYSIS DAN USULAN PENCEGAHAN DI UKM POWER SHUTTLECOCK
}

\author{
Ika Anggraeni Khusnul Khotimah ${ }^{1^{*}}$, Mochammad Bagus Rahmandika ${ }^{2}$, \\ ${ }^{12}$ Teknik Industri,Universitas Merdeka Malang \\ *Korespondensi Penulis, E-mail: ika.anggraeni@unmer.ac.id
}

\author{
Diterima : 14 Oktober 2020 \\ Disetujui : 16 November 2020
}

Direvisi : 2 November 2020

\begin{abstract}
Abstrak
Identifikasi potensi bahaya merupakan salah satu upaya pencegahan terhadap bahaya yang dapat terjadi di suatu tempat atau aktivitas. Pemetaan risiko bahaya yang dapat terjadi sangatlah penting bagi sebuah perusahaan sebagai salah satu cara mengantisipasi terjadinya kecelakaan dan meminimalisir kerusakan. Sehingga dari alasan inilah manajemen risiko terhadap bahaya yang mungkin terjadi menjadi penting untuk perusahaan. Tujuan dari penelitian ini adalah untuk mengidentifikasi bahaya K3 yang dapat terjadi menggunakan metode Failure Mode Effect Analysis (FMEA) dan usulan pencegahan di UKM Power Shuttlecock. Penilaian FMEA dilakukan dengan wawancara kepada pemilik UKM power shuttlecock untuk mendapatkan nilai Risk Priority Number (RPN), berdasarkan nilai RPN tertinggi maka dapat menunjukan risiko bahaya yang dominan dapat terjadi untuk kemudian dilakukan perencanaan dan pengadaan alat dalam rangka pencegahan bahaya. Hasil penelitian berdasarkan analisis menggunakan metode FMEA menunjukkan risiko bahaya yang dominan dapat terjadi di UKM power shuttlecock adalah risiko bahaya kebakaran dengan nilai RPN tertinggi pada setiap proses yang ada di setiap stasiun kerja. Untuk usulan pencegahan potensi bahaya kebakaran adalah dengan pengadaan Alat Pemadam Api Ringan (APAR) yang mengacu pada PERMENAKERTRANS No. Per. 04 / MEN / 1980 untuk menentukan jenis, jumlah dan lokasi penempatan APAR. Maka dibutuhkan APAR ABC chemical powder sebanyak 5 unit, dengan perincian 3 unit $A P A R A B C$ chemical powder berukuran $6 \mathrm{~kg}$ dan 2 unit APAR ABC chemical powder berukuran $3 \mathrm{~kg}$. Total biaya yang dibutuhkan untuk pengadaan APAR sebesar Rp 1.674.000.
\end{abstract}

Kata kunci: Usaha Kecil Menengah (UKM), Failure Mode Effect Analysis (FMEA), Alat Pemadam Api Ringan (APAR), Biaya

\section{Pendahuluan}

Identifikasi potensi bahaya merupakan salah satu upaya pencegahan terhadap bahaya yang dapat terjadi di suatu tempat atau aktivitas. Pemetaan risiko bahaya yang dapat terjadi sangatlah penting bagi sebuah perusahaan sebagai salah satu cara mengantisipasi terjadinya kecelakaan dan meminimalisir kerusakan. Sehingga dari alasan inilah manajemen risiko terhadap bahaya yang mungkin terjadi menjadi penting untuk perusahaan.

Dilansir dari Surya Malang pada tahun 2017 [1] terjadi kebakaran di pabrik dan gudang shuttlecock CV. Unggul Aumireta Malang yang disebabkan oleh konsleting listrik kejadian tersebut terjadi saat pabrik sedang tutup yang dijaga oleh satu orang security. Saat kejadian berlangsung tidak tersedianya APAR di pabrik tersebut. Kejadian ini sangat merugikan perusahaan baik dari sisi finansial dan material, hal ini dapat diantisipasi jika saja terdapat APAR (Alat Pemadam Api Ringan) dan satpam yang berjaga dapat mengoperasikannya. Setiap bangunan setidaknya memiliki 1 jenis APAR siap pakai [2] maka dari itu sangatlah penting untuk memiliki APAR sederhana yang ditempatkan di tempat yang strategis dan rawan terjadinya percikan api untuk mengurangi kemungkinan terjadinya kebakaran yang besar.

Di UKM Power shuttlecock menggunakan berbagai jenis alat dan mesin produksi yang menggunakan energi listrik untuk mengoperasikannya, serta adanya bahan baku yang mudah terbakar seperti bulu angsa, kertas karton, gabus pemberat dan bahan kimia berbahaya seperti lem perekat shuttlecock, lem perekat karton pembungkus dan lain-lain. Hal tersebut telah memenuhi elemen di dalam teori segitiga api [3]. Dalam 
teori segitiga api, api tidak terjadi begitu saja namun terdapat suatu proses kimiawi antara unsur bahan bakar (fuel), oksigen $\left(\mathrm{O}_{2}\right)$ dan panas yang dapat menyebabkan kebakaran. Berdasarkan teori segitiga api maka di UKM power memiliki resiko bahaya kebakaran. Alat penanganan kebakaran di UKM Power Shuttlecock yang tersedia saat ini yaitu hanya menyediakan tong penampungan air yang berjumlah 2 buah namun jumlah ini tidak akan efektif dalam memadamkan api dan juga sangat berbahaya jika terkena benda elektronik dan bahan-bahan yang tidak dapat dipadamkan dengan air.

Namun perlu dilakukan identifikasi potensi bahaya apa saja yang terdapat di UKM Power Shuttlecock sehingga potensi bahaya yang dapat terjadi di masa depan dapat dicegah. Maka dalam penelitian ini bertujuan mengidentifikasi potensi bahaya menggunakan metode failure mode effect analysis dan usulan pencegahan di UKM Power Shuttlecock.

\subsection{Metode}

Tahap pengumpulan data dan pengolahan data yang dilakukan untuk dalam penelitian ini untuk memperoleh informasi dan data terkait dengan objek pengamatan, dengan tahapan sebagai berikut :

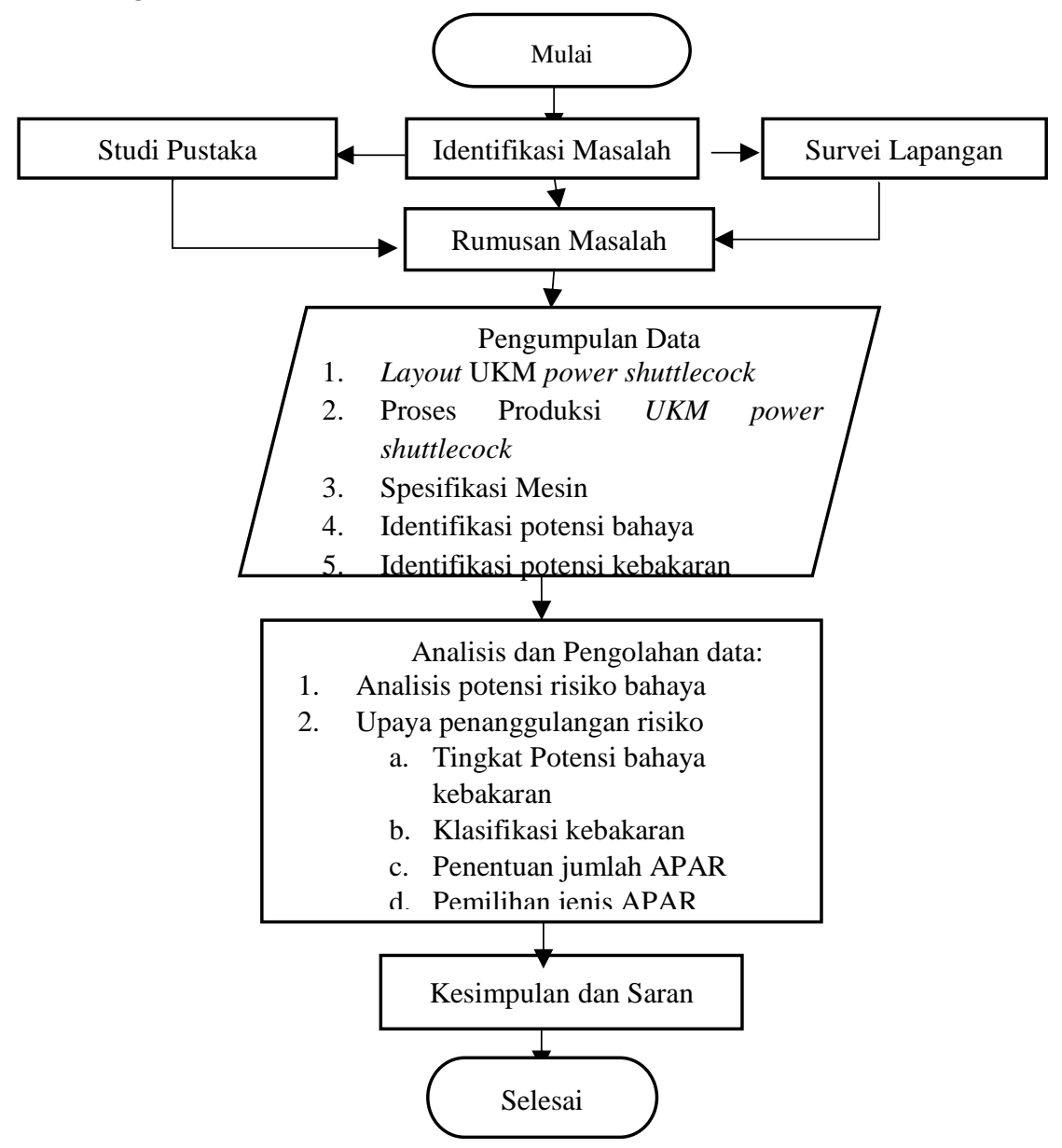

Gambar 1. Flowchart Penelitian 


\subsection{Hasil dan Pembahasan}

\subsubsection{Identifikasi Bahaya}

Berdasarkan hasil proses penilaian kuisioner oleh responden yaitu pemilik usaha dengan pertimbangan faktor $4 \mathrm{M}$ yaitu Man, Machine, Method, dan Material. 4 $M$ ini digunakan untuk mengidentifikasi potensi bahaya $\mathrm{K} 3$ setiap ruangan proses. Analisa tingkat kepentingan yang diprioritaskan dihitung berdasarkan hasil kali ketiga kriteria tersebut atau yang disebut sebagai Risk Priority Number (RPN) [4]. Perhitungan RPN dimaksudkan untuk mengetahui tingkat kekritisan suatu bahaya sehingga perlu segera dilakukan pencegahan. Adapun berikut perhitungan RPN yang telah diurutkan dengan jumlah RPN tertinggi pada setiap ruangan sehingga diketahui potensi bahaya yang dominan disajikan pada tabel berikut :

Tabel 1. Perhitungan RPN

\begin{tabular}{|c|c|c|c|c|c|c|}
\hline No & Ruangan/Proses & Bahaya & $\begin{array}{l}\text { Severity } \\
\text { (S) }\end{array}$ & $\begin{array}{c}\text { Occurance } \\
(0)\end{array}$ & $\begin{array}{l}\text { Detection } \\
\text { (D) }\end{array}$ & RPN \\
\hline \multirow[b]{3}{*}{1} & \multirow{3}{*}{$\begin{array}{c}\text { Ruang Bahan } \\
\text { Baku }\end{array}$} & Pekerja merokok & 9 & 7 & 6 & 378 \\
\hline & & $\begin{array}{c}\text { Tumpukan bahan } \\
\text { baku yang terlalu } \\
\text { tinggi }\end{array}$ & 4 & 3 & 6 & 72 \\
\hline & & $\begin{array}{c}\text { Cedera } \\
\text { punggung saat } \\
\text { mengambil bahan } \\
\text { baku yang tidak } \\
\text { tertata rapi }\end{array}$ & 4 & 2 & 5 & 40 \\
\hline \multirow{5}{*}{2} & \multirow{5}{*}{$\begin{array}{c}\text { Ruang } \\
\text { pengeplongan }\end{array}$} & $\begin{array}{l}\text { Percikan bunga } \\
\text { api dari kabel } \\
\text { terkelupas }\end{array}$ & 8 & 8 & 9 & 576 \\
\hline & & $\begin{array}{l}\text { Konsleting listrik } \\
\text { pada mesin }\end{array}$ & 7 & 7 & 8 & 392 \\
\hline & & Pekerja merokok & 6 & 6 & 7 & 252 \\
\hline & & $\begin{array}{c}\text { Gangguan } \\
\text { pernapasan } \\
\text { karena serpihan } \\
\text { bulu }\end{array}$ & 7 & 4 & 7 & 196 \\
\hline & & $\begin{array}{c}\text { Karyawan } \\
\text { tersengat listrik } \\
\text { dari kabel } \\
\text { terkelupas }\end{array}$ & 8 & 5 & 4 & 160 \\
\hline \multirow{3}{*}{3} & \multirow{3}{*}{$\begin{array}{c}\text { Ruang } \\
\text { pengeboran \& } \\
\text { Gudang } \\
\text { Inventaris }\end{array}$} & $\begin{array}{l}\text { Konsleting listrik } \\
\text { pada mesin }\end{array}$ & 7 & 7 & 8 & 392 \\
\hline & & $\begin{array}{c}\text { Gudang kurang } \\
\text { tertata sehingga } \\
\text { limbah kertas } \\
\text { dapat } \\
\text { menyebabkan } \\
\text { sumber api } \\
\end{array}$ & 9 & 8 & 3 & 216 \\
\hline & & $\begin{array}{c}\text { Gangguan } \\
\text { pernapasan } \\
\text { karena debu } \\
\text { serpihan gabus }\end{array}$ & 5 & 3 & 7 & 105 \\
\hline
\end{tabular}




\begin{tabular}{|c|c|c|c|c|c|c|}
\hline No & Ruangan/Proses & Bahaya & $\begin{array}{l}\text { Severity } \\
(\mathrm{S})\end{array}$ & $\begin{array}{c}\text { Occurance } \\
(0)\end{array}$ & $\begin{array}{l}\text { Detection } \\
\text { (D) }\end{array}$ & RPN \\
\hline & & $\begin{array}{l}\text { Cedera mata } \\
\text { karena serpihan } \\
\text { gabus pada } \\
\text { karyawan }\end{array}$ & 5 & 4 & 5 & 100 \\
\hline \multirow[b]{2}{*}{4} & \multirow[b]{2}{*}{$\begin{array}{c}\text { Ruang } \\
\text { penyimpanan } \\
\text { setengah jadi }\end{array}$} & Pekerja merokok & 9 & 7 & 7 & 441 \\
\hline & & $\begin{array}{c}\text { Gudang kurang } \\
\text { tertata sehingga } \\
\text { limbah kertas } \\
\text { dapat } \\
\text { menyebabkan } \\
\text { rambatan api } \\
\text { yang cepat }\end{array}$ & 9 & 6 & 8 & 432 \\
\hline \multirow[b]{2}{*}{5} & \multirow[b]{2}{*}{$\begin{array}{l}\text { Ruang } \\
\text { pengendali } \\
\text { kualitas } 1 \text { dan } \\
\text { penyetelan }\end{array}$} & Pekerja merokok & 7 & 8 & 7 & 392 \\
\hline & & $\begin{array}{c}\text { Gangguan } \\
\text { pernapasan } \\
\text { karena serpihan } \\
\text { bulu }\end{array}$ & 7 & 4 & 7 & 196 \\
\hline \multirow{3}{*}{6} & \multirow{3}{*}{$\begin{array}{c}\text { Ruang } \\
\text { pengeleman dan } \\
\text { pengeringan }\end{array}$} & $\begin{array}{c}\text { Gangguan } \\
\text { pernapasan } \\
\text { karena bahan } \\
\text { lem } \\
\end{array}$ & 6 & 4 & 7 & 320 \\
\hline & & $\begin{array}{c}\text { Iritasi kulit karena } \\
\text { lem }\end{array}$ & 5 & 6 & 3 & 168 \\
\hline & & $\begin{array}{c}\text { Reaksi kimia } \\
\text { yang dapat } \\
\text { menimbulkan } \\
\text { kebakaran }\end{array}$ & 8 & 5 & 8 & 90 \\
\hline \multirow{5}{*}{7} & \multirow{5}{*}{$\begin{array}{c}\text { Ruang } \\
\text { pengetesan } \\
\text { pukul, pengendali } \\
\text { kualitas } 2 \text { dan } \\
\text { finishing }\end{array}$} & Pekerja merokok & 8 & 6 & 8 & 504 \\
\hline & & Konsleting mesin & 7 & 5 & 8 & 384 \\
\hline & & $\begin{array}{c}\text { Karyawan } \\
\text { tersengat listrik } \\
\text { dari kabel } \\
\text { terkelupas }\end{array}$ & 8 & 3 & 9 & 280 \\
\hline & & $\begin{array}{l}\text { Percikan bunga } \\
\text { api dari kabel } \\
\text { terkelupas } \\
\text { menyebabkan } \\
\text { kebakaran }\end{array}$ & 8 & 7 & 9 & 216 \\
\hline & & $\begin{array}{c}\text { Cedera saat } \\
\text { mengoperasikan } \\
\text { mesin }\end{array}$ & 6 & 3 & 3 & 54 \\
\hline \multirow[b]{2}{*}{8} & \multirow[b]{2}{*}{$\begin{array}{c}\text { Ruang } \\
\text { penyimpanan }\end{array}$} & Pekerja merokok & 8 & 7 & 7 & 392 \\
\hline & & $\begin{array}{c}\text { Tumpukan bahan } \\
\text { baku yang terlalu } \\
\text { tinggi dapat } \\
\text { menimpa }\end{array}$ & 4 & 3 & 3 & 36 \\
\hline
\end{tabular}




\begin{tabular}{|c|c|c|c|c|c|c|}
\hline No & Ruangan/Proses & Bahaya & $\begin{array}{c}\text { Severity } \\
\text { (S) }\end{array}$ & $\begin{array}{c}\text { Occurance } \\
\text { (O) }\end{array}$ & $\begin{array}{c}\text { Detection } \\
\text { (D) }\end{array}$ & RPN \\
\hline \multirow{2}{*}{9} & $\begin{array}{c}\text { Cedera } \\
\text { punggung saat } \\
\text { menata bahan } \\
\text { baku yang } \\
\text { ditumpuk tinggi }\end{array}$ & 4 & 3 & 4 & 48 \\
\hline \multirow{2}{*}{$\begin{array}{c}\text { Pekerja merokok } \\
\text { penyimpanan } \\
\text { slop }\end{array}$} & $\begin{array}{c}\text { Rumpukan bahan } \\
\text { baku yang terlalu } \\
\text { tinggi dapat } \\
\text { menimpa }\end{array}$ & 4 & 7 & 7 & 392 \\
\cline { 2 - 7 } & $\begin{array}{c}\text { Cedera } \\
\text { punggung saat } \\
\text { menata bahan } \\
\text { baku yang } \\
\text { ditumpuk tinggi }\end{array}$ & 4 & 3 & 3 & 36 \\
\hline
\end{tabular}

Dari tabel diatas diketahui bahwa dari pengurutan hasil RPN terbesar, pada setiap ruangan terdapat potensi bahaya kebakaran. Maka usulan pencegahan potensi bahaya terbesar ditujukan untuk mencegah potensi kebakaran, salah satunya dengan usulan pengadaan APAR.

\subsubsection{Tingkat Potensi Kebakaran}

Di lokasi UKM ini belum dilengkapi dengan alat pemadam kebakaran yang memadai., tingkat potensi kebakaran untuk gedung UKM Power shuttlecock berdasarkan hasil observasi lapangan jenis usaha UKM Power shuttlecock tidak tergolong pada salah satu dari jenis tempat kerja yang dijelaskan pada keputusan menteri tenaga kerja No: KEP. 186/MEN/1999 tentang klasifikasi potensi kebakaran. Sehingga dapat disimpulkan bahwa UKM power shuttlecock ini tergolong dalam tingkat potensi bahaya kebakaran sedang II (barang yang disimpan tidak melebihi 4 meter).

\subsubsection{Klasifikasi Kebakaran}

1. Kebakaran tipe A

Salah satu potensi kebakaran yaitu kebakaran yang disebabkan oleh benda non logam seperti dokumen kertas, kayu, dan plastik yang berada di hampir seluruh ruangan UKM Power shuttlecock. Pada tipe kebakaran ini menurut NFPA 10 harus dipadamkan menggunakan tipe APAR air, busa (foam)yang dicampurkan pada gas bertekanan atau tepung kering multipurpose (multipurpose dry chemical).

2. Kebakaran tipe B

Potensi bahaya kebakaran yang kedua yaitu dari reaksi bahan kimia dan cairan, bahaya kebakaran yang disebabkan oleh tumpahan bahan bakar cair adalah sumber kebakaran yang sangat mudah sekali terjadi karena jika terkena panas akan terjadi kebakaran yang cukup besar bahkan dapat menimbulkan ledakan. Pada UKM power shuttlecock ruangan 4 dan 5 menjadi tempat yang rawan terjadi tipe kebakaran ini dikarenakan terdapat bahan kimia yang digunakan dalam proses produksinya dan juga sebagai tempat penyimpanan bahan kimia utama, pada tipe kebakaran ini menurut NFPA harus dipadamkan menggunakan tipe APAR gas $\mathrm{CO}^{2}$ bertekanan, busa 
(foam)yang dicampurkan pada gas bertekanan atau tepung kering multipurpose (multipurpose dry chemical).

\section{Kebakaran tipe C}

Salah satu potensi bahaya kebakaran utama dan mungkin terjadi yang dimaksud yaitu yang berasal dari kelistrikan yang bisa disebabkan dari hubungan arus pendek ataupun kabel yang mengelupas yang dapat menimbulkan percikan api terutama pada ruangan A dan B pada UKM power shuttlecock dikarenakan terdapat banyak sekali peralatan elektronik dan kertas sebagai bahan bakar api, pada tipe kebakaran ini menurut NFPA harus dipadamkan menggunakan tipe APAR yang tidak menghantarkan listrik seperti gas $\mathrm{CO}_{2}$ bertekanan, dry chemical powder khusus atau tepung kering multipurpose (multipurpose dry chemical).

\subsubsection{Kebutuhan APAR}

Pada perencanaan kebutuhan APAR ini peneliti menggunakan standar berdasarkan PERMENAKERTRANS RI NO.04/MEN/1980 [5] tentang kebutuhan APAR.

\section{a. Kebutuhan APAR Berdasarkan Permenakertrans No.4 Tahun 1980}

Berdasarkan [5] tentang Pemasangan dan Pemeliharaan APAR pasal 4, UKM Power Shuttlecock harus menempatkan alat pemadam api ringan (APAR) dengan jarak (D) 15 meter sehingga didapatkan nilai untuk jari-jari ( $r$ ) $=7,5$ meter. Maka penghitungan jumlah APAR berdasarkan kriteria tersebut sebagai berikut:

Luas lantai UKM power shuttlecock $\quad=800 \mathrm{~m}^{2}$

Luas perlindungan per APAR $\quad=\pi \times \mathrm{r}^{2}$

$$
\begin{aligned}
& =3,14 \times(7,5 \mathrm{~m})^{2} \\
& =176,6 \mathrm{~m}^{2}
\end{aligned}
$$

Sehingga untuk menghitung jumlah kebutuhan APAR didapatkan hasil

$$
\begin{aligned}
& =800 \mathrm{~m}^{2}: 176,6 \mathrm{~m}^{2} \\
& =4,5 \rightarrow 5 \text { unit }
\end{aligned}
$$

Dari perhitungan tersebut diketahui perencanaan pengadaan APAR pada UKM power shuttlecock minimal memiliki 5 unit APAR siap pakai.

\section{b. Pemilihan Jenis APAR}

Risiko kebakaran yang dimiliki oleh UKM power shuttlecock yaitu kebakaran yang ditimbulkan dari percikan api kelistrikan termasuk dalam golongan C, yaitu api yang berasal dari kebakaran instalasi listrik bertegangan. Potensi kebakaran yang timbul dari kertas sebagai bahan yang mudah terbakar termasuk dalam golongan $A$, yaitu api yang berasal dari kebakaran bahan padat kecuali logam yang apabila terbakar meninggalkan arang atau abu dan api yang ditimbulkan dari bahan kimia termasuk dalam golongan B yaitu bahan cair atau gas yang mudah terbakar. Jenis kebakaran yang terdapat pada UKM power shuttlecock yaitu kebakaran kelas A, B dan C, sehingga kebutuhan APAR yang akan digunakan harus mencakup ketiga klasifikasi tersebut. Maka perencanaan yang dilakukan peneliti dalam menentukan jenis APAR yang diusulkan di UKM power shuttlecock yaitu: Multipurpose Dry Powder \& Carbon Dioxide $\left(\mathrm{CO}_{2}\right)$

\section{c. Penempatan APAR}

Penempatan APAR mengacu pada Peraturan Menteri Tenaga Kerja dan Transmigrasi No. Per. 04/ Men/ 1980 [5]. Berikut dibawah ini gambar denah peletakan APAR di UKM Power Shuttlecock sebagai berikut : 


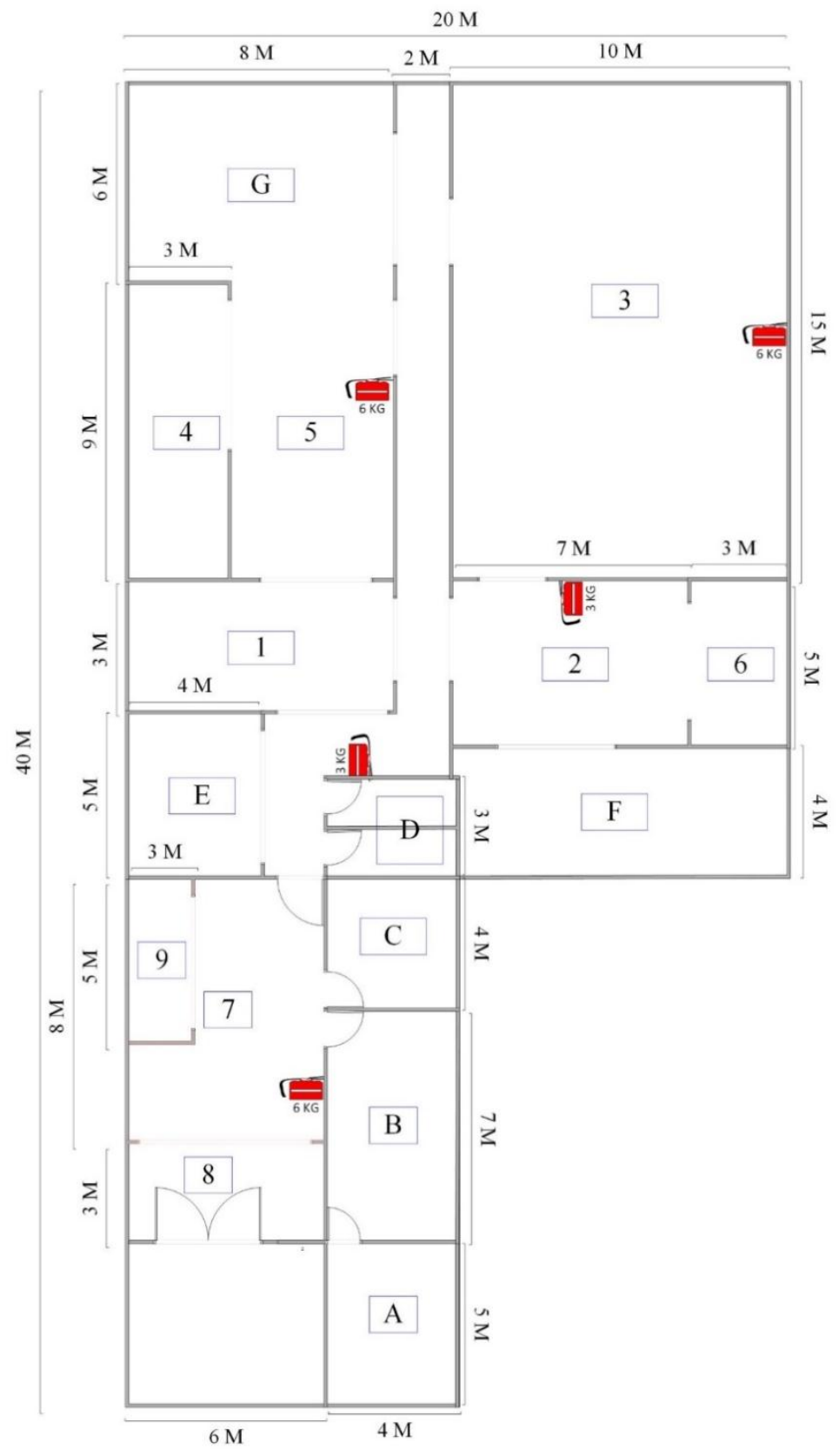

Gambar 2. Denah Peletakan APAR

Keterangan :

\begin{tabular}{|l|l|l|l|}
\hline No & \multicolumn{1}{|c|}{ Area } & $\begin{array}{c}\text { Luas } \\
\text { Ruangan }\end{array}$ & \multicolumn{1}{c|}{ Tipe dan Kapasitas APAR } \\
\hline 1 & $7,8,9, \mathrm{~A}, \mathrm{~B}$ dan $\mathrm{C}$ & $160 \mathrm{~m}^{2}$ & APAR ABC Chemical Powder Ukuran 6 kg \\
\hline 2 & 1, E, dan D & $80 \mathrm{~m}^{2}$ & APAR ABC Chemical Powder Ukuran 3 kg \\
\hline 3 & 2,6, dan F & $90 \mathrm{~m}^{2}$ & APAR ABC Chemical Powder Ukuran 3 kg \\
\hline
\end{tabular}




\begin{tabular}{|l|l|l|l|}
\hline 4 & 3 & $150 \mathrm{~m}^{2}$ & APAR ABC Chemical Powder Ukuran $6 \mathrm{~kg}$ \\
\hline 5 & 4,5, dan 6 & $120 \mathrm{~m}^{2}$ & APAR ABC Chemical Powder Ukuran $6 \mathrm{~kg}$ \\
\hline
\end{tabular}

\section{d. Perhitungan Biaya Pengadaan APAR}

Setelah didapatkan jumlah dan jenis APAR, selanjutnya dilakukan perhitungan biaya untuk pengadaan APAR. Data perhitungan biaya pengadaan APAR dapat dilihat dalam tabel dibawah ini :

Tabel 2. Permenakertrans No.04/Men/1980

\begin{tabular}{|l|l|l|l|}
\hline Jenis APAR & Jumlah (Unit) & Harga/unit & Total harga \\
\hline $\begin{array}{l}\text { Multipurpose Chemical } \\
\text { Powder 3 Kg }\end{array}$ & 2 unit & Rp 234.000/unit & $\operatorname{Rp~468.000~}$ \\
\hline $\begin{array}{l}\text { Multipurpose Chemical } \\
\text { Powder 6 Kg }\end{array}$ & 3 unit & Rp 377.000/unit & Rp 1.131.000 \\
\hline Simbol APAR & 5 unit & Rp 15.000/unit & Rp 75.000 \\
\hline Total Biaya & & Rp.1.674.000 \\
\hline
\end{tabular}

Berdasarkan penghitungan biaya yang telah dihitung diatas, dapat diketahui biaya yang harus disiapkan untuk pengadaan pembelian APAR dan peralatan pendukungnya dibutuhkan biaya sebesar Rp. 1.674.000.

\section{Kesimpulan}

1. Berdasarkan hasil analisis menggunakan metode FMEA risiko bahaya yang lebih dominan dapat terjadi di UKM power shuttlecock adalah risiko bahaya kebakaran, dengan RPN tertinggi pada setiap proses stasiun kerja.

2. Usulan metode pencegahan potensi kebakaran adalah dengan pengadaan APAR ABC chemical powder sebanyak 5 unit, dengan perincian 3 unit APAR ABC chemical powder berukuran $6 \mathrm{~kg}$ dan 2 unit APAR ABC chemical powder berukuran $3 \mathrm{~kg}$. Lokasi penempatan APAR mengacu pada Permenakertrans No. Per. 04/ MEN/ 1980 dengan biaya pengadaan sebesar Rp 1.674.000.

\section{Daftar Pustaka}

[1] Zainuddin. (2017). Kebakaran Gudang di Singosari, Kabupaten Malang Viral, Netizen Berharap Tak Ada Korban, diakses dari https://suryamalang.tribunnews.com/2017/11/14/kebakarangudang- di-singosarikabupaten-malang-viral-netizen-berharap-tak-ada-korban, pada 15 juli 2019.

[2] Peraturan Menteri Tenaga Kerja dan Transmigrasi No. Per.186/ MEN/ 1999, Tentang Unit Penanggulangan Kebakaran di Tempat Kerja.

[3] Ramli, Soehatman. (2010). Petunjuk Praktis Manajemen Kebakaran (fire management). Jakarta: Dian Rakyat.

[4] Kartikasari, V., \& Romadhon, H. (2019). Analisis Pengendalian dan Perbaikan Kualitas Proses Pengalengan Ikan Tuna Menggunakan Metode Failure Mode and Effect Analysis (FMEA) dan Fault Tree Analysis (FTA) Studi Kasus di PT.XXX Jawa Timur. Journal of Industrial View Vol. 01, No.01. Halaman 1-10.

[5] National Fire Protection Association (NFPA) 10. (2013). Standart for portable fire extinguishers. USA.

[6] Peraturan Menteri Tenaga Kerja dan Transmigrasi No. Per.04/ MEN/ 1980, Tentang Syarat-Syarat Pemasangan dan Pemeliharaan Alat Pemadam Api. 